\title{
Sleep Disorders in Neurodegenerative Disorders
}

\author{
Jong-Geun Seo ${ }^{1}$, Sung-Pa Park ${ }^{1}$, Ho-Won Lee ${ }^{1,2}$ \\ ${ }^{1}$ Department of Neurology, School of Medicine, Kyungpook National University, Daegu, \\ ${ }^{2}$ Brain Science \& Engineering Institute, Kyungpook National University, Daegu, Korea
}

\section{신경퇴행성 질환의 수면장애}

서종근 ${ }^{1}$, 박성파$^{1}$, 이호원 ${ }^{1,2}$

경북대학교 의학전문대학원 신경과학교실, ${ }^{1}$ 경북대학교 뇌과학연구소 ${ }^{2}$

\author{
Received May 3, 2014 \\ Revised May 21, 2014 \\ Accepted May 21, 2014 \\ Address for correspondence \\ Ho-Won Lee, MD, PhD \\ Department of Neurology, \\ School of Medicine, \\ Brain Science \& Engineering \\ Institute, Kyungpook \\ National University, \\ 680 Gukchaebosang-ro, Jung-gu, \\ Daegu 700-842, Korea \\ Tel: +82-53-200-3271 \\ Fax: +82-53-200-3299 \\ E-mail: neuromd@knu.ac.kr
}

\begin{abstract}
Neurodegenerative diseases result from deterioration of neurons which may eventually lead to central nervous system-related dysfunction including sleep disorders. The pathogenesis of these disturbances may be secondary to direct structural alterations of the sleep-wake generating cells and networks or be the consequence of several indirect mechanisms. The most frequent sleep disturbances in patients with neurodegenerative diseases are insomnia, hypersomnia, parasomnias, excessive nocturnal motor activity, circadian sleep-wake rhythm disturbances, and respiratory dysrhythmias. Here, we classify the neurodegenerative diseases, taking into consideration the type of molecular neurodegeneration as synucleinopathies and tauopathies and reviewed sleep disorders observed in each degeneration type. The aim of this review is to provide data on sleep disturbances in two categories of neurodegenerative disorders.
\end{abstract}

J Korean Sleep Res Soc 2014;11(1):1-4

Key Words: Neurodegenerative diseases, Sleep disorders, Parkinsonism, Dementia.

\section{서 론}

최근 우리나라는 고령화 사회로 접어들었고, 2018년에는 65 세 이상의 노인 인구가 전체 인구의 $14 \%$ 를 넘어서는 고령 사회로 진입될 것으로 예상된다. 노령 인구가 증가할수록 치 매나 파킨슨병과 같은 신경퇴행성 질환의 유병률이 급격히 증가하게 된다. 신경퇴행성 질환은 중추신경계의 신경세포 에 퇴행성 변화로 인해 치매, 추체외로계 이상 등의 다양한 증상을 나타내며 수면장애도 흔히 동반되는 것으로 알려져 있다. 수면장애는 다양한 질병을 일으키고, 각종 만성 질환을 악화시키는 위험인자로 작용한다고 알려져 있다. 또한, 신경 퇴행성 질환은 증상이 비가역적으로 진행하며 동반된 수면 장애는 요양병원에 조기에 입원하게 되는 원인이 된다. 본 종설에서는 신경퇴행성 질환을 크게 synucleinopathies와

This is an Open Access article distributed under the terms of the Creative Commons Attribution Non-Commercial License (http://creativecommons.org/licenses/by-nc/3.0) which permits unrestricted non-commercial use, distribution, and reproduction in any medium, provided the original work is properly cited. tauopathies로 나누어 각각의 질환에서 동반되는 수면장애에 대해 살펴보고자 한다.

\section{Synucleinopathies}

파킨슨병(Parkinson's disease)

파킨슨병은 흑질의 도파민성 신경세포의 소실을 초래하는 질환으로, 알츠하이머병에 이어 두 번째로 흔한 신경퇴행성 질환이다. 세계적 유병률은 선진국에서 $0.3 \%, 60$ 세 이상의 경우 $1 \%$ 정도이며, 발병률은 1 년에 10 만 명당 8 18명으로 알려져 있다. ${ }^{1}$ 임상적으로는 운동완만, 근경직의 증가, 안정 떨림, 비정상적인 자세 반사, 행동의 동결, 자세 변화 등의 증 상이 나타나며, 수면장애도 흔히 동반되는 것으로 알려져 있 다. ${ }^{2}$ 파킨슨병에서 수면장애는 여러 가지 원인으로 설명하는 데, 병 자체와 연관되어서 뇌간의 수면-각성과 연관된 구조 물들이 퇴행성 변화를 하는 것과, 그로 인한 운동장애, 호흡 장애, 자율신경계 장애 등이 원인이 될 수 있다. ${ }^{2}$ 한 연구에 
의하면 파킨슨병의 $49 \%$ 에서 수면장애를 호소하며, ${ }^{3}$ 수면장 애 중 불면증(37\%), 렘수면행동장애(30\%), 주간과다졸림증 (21\%), 그리고 하지불안증후군(15\%)이 동반된다고 보고되어 있다. ${ }^{4}$

불면증은 파킨슨병에서 가장 흔한 수면장애로 수면 유지 장애가 흔하게 발생한다. 수면 분절은 모든 수면 단계에서 발 생할 수 있지만, 주로 비렘수면의 N1과 N2 단계에서 발생한 다. ${ }^{5}$ 불면증은 주로 파킨슨병의 증상인 강직성 및 운동완만으 로 인해 수면 중 자세 변경이 어려워 발생하며, 복용 중인 도 파민성 약제로 인해 발생하기도 한다. 도파민성 약제는 야간 수면의 질에 상당한 영향을 미치며, 야간 활동을 증가시키고 수면 분절을 유발한다고 알려져 있다. 또한, 파킨슨병에 동반 된 우울과 불안은 조기 각성과 일주기 리듬수면장애를 유발 하기도 한다. ${ }^{6}$

파킨슨병에서 렘수면행동장애는 진단 방법에 따라 매우 다양하게 보고되고 있다. 병력으로 진단하는 경우는 $15 \%$ 에 서 동반된다고 보고하였고 수면다원검사를 통해 진단한 경 우는 $50 \%$ 이상의 빈도로 보고하고 있다. 파킨슨병에서 동반 된 렘수면행동장애는 특정한 운동 증상과 연관이 있는데, 진 전을 동반하지 않는 강직-자세 불안정을 보이는 환자에서 더 흔히 동반된다. ${ }^{8}$ 파킨슨병의 유병기간이나 복용 중인 도파민 성 약제의 용량, 운동 증상의 심한 정도와의 연관성은 명확히 밝혀져 있지 않다. 그러나 렘수면행동장애는 파킨슨병의 어 느 단계에서든 발생할 수 있고 파킨슨병 환자의 $17.8 \%$ 에서 는 렘수면행동장애가 파킨슨 증상보다 먼저 발생을 한다고 알려져 있다. ${ }^{9}$ 이는 렘수면행동장애가 신경퇴행성 질환의 위 험 인자는 아니지만 파킨슨병의 초기 증상으로 나타날 수 있 음을 의미한다. ${ }^{10}$ 그리고 렘수면행동장애가 뇌간 부위의 병변 에 의해 발생하므로 파킨슨병이 진행할수록 렘수면행동장애 를 동반할 가능성이 높을 것으로 추정할 수 있다. ${ }^{8}$

파킨슨병에서 주간과다졸림증은 정상 인구에 비해 더 흔 하게 나타나며 연구에 따라 15.5 29\%에서 동반되는 것으로 보고되어 있다. ${ }^{11}$ 주간과다졸림증은 수면 각성 주기를 조절하 는 중요한 영역인 뇌간, 시상, 시상하부 및 피질의 손상이 원 인이 될 수 있으며, 시상하부에 있는 멜라토닌을 분비하는 hypocretin 신경 세포의 손실을 가진 파킨슨병 환자는 환각 과 야간 불면증을 야기하여 주간과다졸림증을 유발할 수 있 다. ${ }^{12,13}$ 주간과다졸림증은 파킨슨 증상보다 선행하기도 하며 병의 진행과 도파민성 약제와 연관성이 있어 운동 증상을 조 절하기 위해 고용량의 도파민성 약제를 사용할 때 심해질 수 있다. ${ }^{12}$

파킨슨병에서 하지불안증후군은 흔히 동반되는 수면장애 이며 일반 인구에 비해 높다고 보고되어 있다. ${ }^{14}$ 이전 연구에
의하면 일반 인구에서는 5 10\%에서 동반되며 파킨슨병에서 는 15 20\%에서 동반된다고 알려져 있으나, 증상만으로 파킨 슨병으로 인한 비운동성 증상과 하지불안증후군과의 감별이 어려운 한계가 있다..$^{15}$ 파킨슨병과 하지불안증후군은 공통적 으로 중추신경계에서 도파민 시스템의 변화에 의해 야기되 는 병태 생리학적 특성을 가진다. 그러나 파킨슨병에서 도파 민성 기능장애는 주로 흑질 선조체와 중변연계 이상에 의해 발생지만, 하지불안증후군에서는 간뇌-척수 시스템의 이상 에 의해 발생한다. ${ }^{15}$ 현재까지는 파킨슨병과 하지불안증후군 의 연관성이나 서로가 위험 인자인지에 대한 명확한 증거는 없다.

파킨슨병에서 수면호흡장애는 아직 광범위하게 연구되지 않았다. 폐쇄수면무호흡은 수면호흡장애의 가장 흔한 유형 이며, 수면호흡장애의 유병률이 파킨슨병과 일반 인구와의 차이가 있는지는 명확하지 않다. 또한 폐쇄수면무호흡은 파 킨슨병의 질병 기간, 증상의 정도, 약물과의 상관 관계는 없 는 것으로 알려져 있다. ${ }^{16}$

\section{다계통위축증(Multiple system atrophy)}

다계통위축증은 드문 신경퇴행성 질환으로, 파킨슨증이 있으면서 자율신경기능장애나 소뇌실조증이 동반된다. 파킨 슨병과 마찬가지로 synucleinopathy로 분류되나 파킨슨병과 는 달리 치료에 반응이 좋지 않고 예후도 파킨슨병에 비해 안 좋다. ${ }^{17}$ 운동장애가 심한 편이고 호흡 중추나 수면 시스템과 깊은 연관이 있는 자율 신경계 손상이 동반되어 파킨슨병에 비해 심한 수면장애가 동반될 것으로 예상되지만 다계통위 축증에서 수면장애에 대한 연구는 많지 않다.

다계통위축증에서 수면호흡장애는 흔하게 동반된다고 알 려져 있으며, 그 중 야간 천명과 폐쇄수면무호흡이 가장 흔하 다. ${ }^{18}$ 다계통위축증에서 폐쇄수면무호흡은 $15 ~ 37 \%$ 에서 동반 되며, 천명은 13 69\%에서 동반된다. 18,19 야간 천명과 수면 무 호흡은 같은 기전을 가지지는 않지만 종종 동시에 발생하기 도 한다. ${ }^{19}$ 수면 무호흡은 수면 중 상기도 근육의 운동 저하로 인해 발생할 수 있으며, 의핵(nucleus ambiguus)의 변성으로 성대 외전근의 위축과 마비로 인해 발생한다고 알려져 있 다. ${ }^{20}$ 폐쇄수면무호흡은 운동 증상의 정도와 연관성이 있으며 심한 다계통위축증 환자는 수면 동안 앙와위로만 누울 수 있 어 수면 무호흡이 더 심해지게 된다. ${ }^{18}$

천명은 일반적으로 거칠고 고음의 소리로 나타나 심한 코 골이와 구별된다. 천명은 주로 질병의 후반부에 나타나지만 초기에 발생하는 경우도 있다. 다계통위축증에서 천명은 성 대기능장애에 의한 후두 협착에 의해 발생하는 것으로 알려 져 있다. 수면 중 발생하는 천명은 성대 내전근의 과다활동과 
성대 외전근의 저활동으로 인해 상기도 저항이 증가되어 발 생하며 이는 후두신경의 활동을 조절하는 뇌줄기 기능의 장 애로 발생한다. ${ }^{21}$ 다계통위축증에서 천명은 호흡부전, 수면 도 중 급사, 생존기간 단축과 연관이 있는 것으로 알려져 있어 조기에 발견하여 적절한 치료를 하는 것이 중요하다. ${ }^{17}$

다계통위축증에서도 렘수면행동장애가 흔히 발생하는 것 으로 알려져 있다. 다계통위축증에서 렘수면행동장애는 $90 \%$ 이상에서 동반되는 흔한 수면장애이며 파킨슨병처럼 다계통 위축증 발병 전에 나타나기도 한다. ${ }^{9}$ 파킨슨병에 비해 다계통 위축증에서 렘수면행동장애가 더 흔히 동반되는 원인에 대 해서는 불분명하다. 그러나 다계통위축증이 파킨슨병에 비 해 신경퇴행성 변화가 훨씬 더 광범위하고, 렘수면시 근육 이 완과 연관된 뇌간의 위축을 유발하기 때문인 것으로 알려져 있다. ${ }^{9}$

\section{레비소체치매(Dementia with Lewy bodies)}

레비소체치매는 알츠하이머병에 이어 두 번째로 흔하며, 특징적으로 대뇌 피질, 피질, 그리고 뇌간 구조물에 레비소체 침착을 보인다. 레비소체치매는 진행하는 인지기능 저하, 인 지기능의 변동, 반복적인 환시와 파킨슨 증상을 특징으로 한 다. ${ }^{22}$ 레비소체치매에서 동반되는 수면장애에 대해서는 체계 적으로 연구된 적이 없지만, 렘수면행동장애와의 연관성은 보고되어 있으며 흔하게 동반된다고 알려져 있다. ${ }^{23}$ 렘수면행 동장애는 레비소체치매의 인지기능 이상이 발생하기 전에 선행한다고 보고되어 있으며, 2005년 레비소체치매의 진단 기준에 주요한 증상으로 추가되었다. ${ }^{24}$ 따라서, 레비소체치매 가 의심되는 환자에서는 렘수면행동장애의 증상이 있을 경 우 수면다원검사를 시행하여 확인하는 것이 필요하다.

\section{Taupathies}

\section{알츠하이머병(Alzheimer's disease)}

알츠하이머병은 치매 중 가장 흔하며, 주로 측두엽과 두정 엽에 손상이 와서 병의 초기에 기억장애나 시공간 능력 장애 등의 인지기능장애가 나타나는 퇴행성 질환이다. ${ }^{25}$ 알츠하이 머병에서 수면장애는 수면 주기의 변화가 오고 수면 중 각성 의 시간이나 횟수가 증가한다. 이로 인해 서파 수면과 렘수면 이 감소하고 과도한 주간 수면 과다를 호소한다. ${ }^{26}$ 알츠하이 머병은 폐쇄수면무호흡이 33 53\%에서 동반된다고 보고되 어 있으며, 이는 야간 수면에 악영향을 미치며 주간 수면 과 다를 유발하게 된다. 또한 질병의 인지기능을 악화시킬 수도 있다. ${ }^{27}$ 알츠하이머병과 폐쇄수면무호흡에서 몇 가지 공통된 병인을 가지고 있는데, 그 중 아포지질단백 $\mathrm{E} 4$ 유전자는 두
질병 발생의 위험인자로 알려져 있다. 28,29 또한, 콜린성 작용 이 상부 기도의 개방에 영향을 미치는데 알츠하이머병에서 는 콜린성 전달의 장애가 있어 이로 인해 수면 무호흡증을 유 발할 수 있다..$^{0}$ 그러나 알츠하이머병에서 일반 인구에 비해 폐쇄수면무호흡이 더 흔히 동반되는지에 대해서는 불명확하 다.

\section{다른 질환들}

전두측두엽치매(frontotemporal dementia)는 알츠하이머 병과 구분되는 독특한 신경퇴행성 질환이다. 전두측두엽치 매는 전두엽과 측두엽에 병변이 발생하며, 성격 변화나 이상 행동, 혹은 언어장애로 시작하고 상대적으로 기억력이나 방 향감각은 유지된다. ${ }^{31}$ 전두측두엽치매에서의 수면장애는 많 이 연구되어 있지는 않지만, 최근 한 연구에 의하면 수면-각 성장애가 흔히 동반된다고 보고되었다. 알츠하이머병은 아 침에 활동이 적고 저녁이나 밤에 활동이 심해지는 양상을 보 이나, 전두측두엽치매는 하루 종일 지속적인 활동을 보이는 차이점이 있다. 그래서 수면-각성장애의 양상이 두 질환을 감별할 수 있을 것이라고 제안하였다. ${ }^{2}$ 이외에는 렘수면행동 장애와 같이 뇌간 기능의 이상으로 인해 발생하는 수면장애 에 대해서는 보고된 바가 없다.

피질기저핵변성(corticobasal degeneration)은 대뇌 피질과 피질하 조직의 이상으로 인해, 레보도파에 잘 반응하지 않는 비대칭적 무운동성-경직 증후군, 근이긴장증, 실행증, 피질 성 감각 소실 등이 동반되는 질환이다. 과거에는 피질기저핵 변성이 주로 이상운동 증상을 유발하는 질환으로 분류되어 왔으나, 인지기능장애를 동반하는 것으로 알려지면서 신경 퇴행성 질환의 하나로 인식되어졌다. ${ }^{33}$ 피질기저핵변성은 드 문 질환으로 수면장애에 대해서는 광범위하게 연구된 바가 없으나 렘수면행동장애가 동반된 보고가 있었는데, tau pathology에서 렘수면행동장애가 동반될 수 있다는 것을 보여 준 사례였다. ${ }^{34}$

진행성핵상마비(progressive supranuclear palsy)는 파킨슨 증후군의 한 종류로 파킨슨증과 자세 불안정, 수직안구운동 마비, 인지기능 저하 등을 특징으로 한다. ${ }^{35}$ 진행성핵상마비 에서 수면장애는 대부분 동반된다고 보고되어 있다. 그 중 불 면증이 가장 흔히 동반되며 알츠하이머병에 비해 훨씬 더 심 한 것으로 알려져 있으며, 렘수면행동장애가 동반된다는 보 고도 있었다..$^{36}$ 이는 진행성핵상마비가 뇌간 침범을 더 많이 하기 때문인 것으로 알려져 있다. ${ }^{37}$ 


\begin{abstract}
결 론
수면은 우리 삶의 $1 / 3$ 을 차지하며, 신체 기능의 회복과 항 상성 유지의 중요한 역할을 한다. 신경퇴행성 질환에서의 수 면장애는 다양하고 흔하게 동반된다. 수면장애는 신경퇴행 성 질환을 가진 환자의 일상 생활 기능을 저하시키고 질병 자 체에도 영향을 줄 수 있으며, 이로 인해 삶의 질의 저하를 가 져오게 한다. 따라서 신경퇴행성 질환을 가진 환자를 진료할 때 수면장애의 동반 여부에 대해 적절한 평가를 통해 치료를 시행함으로써 환자 및 보호자의 삶의 질의 향상을 기대할 수 있을 것이다.
\end{abstract}

\section{REFERENCES}

1. de Lau LM, Breteler MM. Epidemiology of Parkinson's disease. Lancet Neurol 2006;5:525-535.

2. Oerlemans WG, de Weerd AW. The prevalence of sleep disorders in patients with Parkinson's disease. A self-reported, community-based survey. Sleep Med 2002;3:147-149.

3. Riedel O, Klotsche J, Spottke A, et al. Frequency of dementia, depression, and other neuropsychiatric symptoms in 1,449 outpatients with Parkinson's disease. J Neurol 2010;257:1073-1082.

4. Barone P, Antonini A, Colosimo C, et al. The PRIAMO study: a multicenter assessment of nonmotor symptoms and their impact on quality of life in Parkinson's disease. Mov Disord 2009;24:1641-1649.

5. Porter B, Macfarlane R, Walker R. The frequency and nature of sleep disorders in a community-based population of patients with Parkinson's disease. Eur J Neurol 2008;15:50-54.

6. Raggi A, Bella R, Pennisi G, Neri W, Ferri R. Sleep disorders in Parkinson's disease: a narrative review of the literature. Rev Neurosci 2013;24: 279-291.

7. Kumru H, Santamaria J, Tolosa E, et al. Rapid eye movement sleep behavior disorder in parkinsonism with parkin mutations. Ann Neurol 2004;56:599-603.

8. Postuma RB, Gagnon JF, Vendette M, Charland K, Montplaisir J. REM sleep behaviour disorder in Parkinson's disease is associated with specific motor features. J Neurol Neurosurg Psychiatry 2008;79:1117-1121.

9. Iranzo A, Santamaría J, Rye DB, et al. Characteristics of idiopathic REM sleep behavior disorder and that associated with MSA and PD. Neurology 2005;65:247-252.

10. Iranzo A, Molinuevo JL, Santamaría J, et al. Rapid-eye-movement sleep behaviour disorder as an early marker for a neurodegenerative disorder: a descriptive study. Lancet Neurol 2006;5:572-577.

11. Ghorayeb I, Loundou A, Auquier P, Dauvilliers Y, Bioulac B, Tison F. A nationwide survey of excessive daytime sleepiness in Parkinson's disease in France. Mov Disord 2007;22:1567-1572.

12. Rye DB, Bliwise DL, Dihenia B, Gurecki P. Fast track: daytime sleepiness in Parkinson's disease. J Sleep Res 2000;9:63-69.

13. Thannickal TC, Lai YY, Siegel JM. Hypocretin (orexin) cell loss in Parkinson's disease. Brain 2007;130(Pt 6):1586-1595.

14. Ondo WG, Vuong KD, Jankovic J. Exploring the relationship between Parkinson disease and restless legs syndrome. Arch Neurol 2002;59: 421-424.

15. Iranzo A, Comella CL, Santamaria J, Oertel W. Restless legs syndrome in Parkinson's disease and other neurodegenerative diseases of the central nervous system. Mov Disord 2007;22 Suppl 18:S424-S430.

16. Cochen De Cock V, Abouda M, Leu S, et al. Is obstructive sleep apnea a problem in Parkinson's disease? Sleep Med 2010;11:247-252.

17. Stefanova N, Bücke P, Duerr S, Wenning GK. Multiple system atrophy: an update. Lancet Neurol 2009;8:1172-1178.

18. Vetrugno R, Provini F, Cortelli P, et al. Sleep disorders in multiple system atrophy: a correlative video-polysomnographic study. Sleep Med 2004;5:21-30.

19. Ghorayeb I, Bioulac B, Tison F. Relationship between stridor and sleep apnoea syndrome: is it as simple as that? J Neurol Neurosurg Psychiatry 2004;75:512-513; author reply 513.

20. Bannister R, Gibson W, Michaels L, Oppenheimer DR. Laryngeal abductor paralysis in multiple system atrophy. A report on three necropsied cases, with observations on the laryngeal muscles and the nuclei ambigui. Brain 1981;104:351-368.

21. Hayashi M, Isozaki E, Oda M, Tanabe H, Kimura J. Loss of large myelinated nerve fibres of the recurrent laryngeal nerve in patients with multiple system atrophy and vocal cord palsy. J Neurol Neurosurg Psychiatry 1997;62:234-238.

22. Weiner MF. Dementia associated with Lewy bodies: dilemmas and directions. Arch Neurol 1999;56:1441-1442.

23. Boeve BF, Silber MH, Ferman TJ, et al. REM sleep behavior disorder and degenerative dementia: an association likely reflecting Lewy body disease. Neurology 1998;51:363-370.

24. McKeith IG, Dickson DW, Lowe J, et al. Diagnosis and management of dementia with Lewy bodies: third report of the DLB Consortium. Neurology 2005;65:1863-1872.

25. Dickson DW. Neuropathological diagnosis of Alzheimer's disease: a perspective from longitudinal clinicopathological studies. Neurobiol Aging 1997;18(4 Suppl):S21-S26.

26. Vitiello MV, Borson S. Sleep disturbances in patients with Alzheimer's disease: epidemiology, pathophysiology and treatment. CNS Drugs 2001;15:777-796.

27. Chokroverty S. Sleep, breathing, and neurological disorders. In: Chokroverty S. Sleep Disorders Medicine: Basic Science, Technical Considerations, and Clinical Aspects. 2nd ed. Boston: Butterworth Heinemann, 1999;509-571.

28. Kadotani H, Kadotani T, Young T, et al. Association between apolipoprotein E epsilon4 and sleep-disordered breathing in adults. JAMA 2001;285:2888-2890.

29. Bliwise DL. Sleep apnea, APOE4 and Alzheimer's disease 20 years and counting? J Psychosom Res 2002;53:539-546.

30. Bellingham MC, Ireland MF. Contribution of cholinergic systems to state-dependent modulation of respiratory control. Respir Physiol Neurobiol 2002;131:135-144.

31. Rosen HJ, Lengenfelder J, Miller B. Frontotemporal dementia. Neurol Clin 2000;18:979-992.

32. Anderson KN, Hatfield C, Kipps C, Hastings M, Hodges JR. Disrupted sleep and circadian patterns in frontotemporal dementia. Eur J Neurol 2009;16:317-323.

33. Litvan I, Cummings JL, Mega M. Neuropsychiatric features of corticobasal degeneration. J Neurol Neurosurg Psychiatry 1998;65:717-721.

34. Wetter TC, Brunner H, Collado-Seidel V, Trenkwalder C, Winkelmann J. Sleep and periodic limb movements in corticobasal degeneration. Sleep Med 2002;3:33-36.

35. Birdi S, Rajput AH, Fenton M, et al. Progressive supranuclear palsy diagnosis and confounding features: report on 16 autopsied cases. Mov Disord 2002;17:1255-1264.

36. Arnulf I, Merino-Andreu M, Bloch F, et al. REM sleep behavior disorder and REM sleep without atonia in patients with progressive supranuclear palsy. Sleep 2005;28:349-354.

37. Bhatt MH, Podder N, Chokroverty S. Sleep and neurodegenerative diseases. Semin Neurol 2005;25:39-51. 